\title{
Environmental impact assessment in a company
}

\section{Evaluación de impacto ambiental en una empresa}

TAVERA-CORTÉS, María Elena†, SANDOVAL-GÓMEZ, Raúl Junior and VERGEL-RANGEL, Guillermo Alexis

Instituto Politécnico Nacional, UPIICSA

ID $1^{\text {st }}$ Author: María Elena, Tavera-Cortés

ID $1^{\text {st }}$ Coauthor: Raúl Junior, Sandoval-Gómez

ID $2^{\text {nd }}$ Coauthor: Guillermo Alexis, Vergel-Rangel

DOI: $10.35429 / J F E .2019 .5 .3 .1 .10$

Received July 29, 2019; Accepted December 20, 2019

\begin{abstract}
This article addresses the environmental impact in an enterprise of the agricultural sector through the analysis of the life cycle of the nopal brine elaboration, where the identified impact categories were identified for their evaluation as well as the opportunities for improvement. The methodology used followed a cradle to gate approach, from the nopal vegetable growing area in Milpa Alta, Mexico City, to the processing stage in the company; the functional unit was a ton of nopal in brine and the software used was SimaPro V8.5.2.
\end{abstract}

Environmental impact, Life Cycle Analysis, SimaPro, Nopal, Milpa Alta

\begin{abstract}
Resumen
Este artículo aborda el impacto ambiental en una empresa del sector agrícola mediante el análisis del ciclo de vida de la elaboración del nopal salmuera, donde se procedió a la identificación de las categorías de impacto especificadas para su evaluación, así como las oportunidades de mejora. La metodología utilizada siguió un enfoque de la cuna a la puerta (cradle to gate), desde la zona de cultivo de nopal verdura en Milpa Alta, Ciudad de México, hasta la etapa de procesado en la empresa; la unidad funcional fue una tonelada de nopal en salmuera y el software utilizado fue SimaPro V8.5.2.

Impacto ambiental, Análisis de Ciclo de Vida, SimaPro, Nopal, Milpa Alta
\end{abstract}

Citation: TAVERA-CORTÉS, María Elena, SANDOVAL-GÓMEZ, Raúl Junior and VERGEL-RANGEL, Guillermo Alexis. Environmental impact assessment in a company. RINOE Journal-Financial Economy. 2019. 3-5: 1-10.

$\dagger$ Researcher contributing first author. 


\section{Introduction}

In socioeconomic terms, the agricultural sector represents a key player in the growth of Mexico (Ayala et al., 2011), contributing $3.607 \%$ of the Gross Domestic Product (GDP) for 2015 (World Bank, 2016); In terms of occupation, the agricultural sector in Mexico constitutes an important driver of employment, occupying $17.52 \%$ of the economically active population. Globally, Mexico has an important presence in the agricultural market, ranking 10th in world food production. (SIAP, 2018). In contrast, from the environmental aspect, the agricultural sector in Mexico represents one of the activities with the greatest negative impact on the environment, because according to the National Inventory of Greenhouse Gases (INEGEI) published in 2013, it ranks second in emissions of greenhouse gases (GHG) into the atmosphere (SEMARNAT, 2013), in addition, it is also responsible for problems such as overexploitation and pollution of aquifers, loss of biological diversity, deforestation, and soil degradation and pollution (Santoyo et al, 2013).

In that order of ideas, the agricultural sector in Mexico has important opportunities for improvement (Vega Campos, Medina Jiménez and Vega Juárez, 2013) around the restructuring of sustainable production systems, which ensure food security and guarantee consumer health (Paz García et al, 2018). In view of this need, the present investigation arises, whose main objective was "To evaluate the environmental impact in a nopal producing and processing company of the Milpa Alta area, CDMX".

The methodological strategy carried out consisted of a mixed research approach of a descriptive nature through the application of a case study in a nopal producing and processing company. Using the SimaPro V8.5.2 software, the Environmental Impact Assessment (EIA) was carried out taking into account data extracted from the company and secondary sources, mainly from research articles such as "Ecology of cultivation, management and uses of prickly pear cactus , Bulletin of Agricultural Services "and" Conservation of nopal vegetable 'Milpa Alta' (opuntia ficus mdica mill.) Despiled in containers with modified atmosphere ", ISO standards and official databases referring to the sector such as the stages of cultivation or sectors affected in the production of the cactus,.
Once the environmental impact
categories were quantified, important opportunities for improvement were identified in the case study company, especially related to the fertilization used and the absence of an integral management of its organic waste.

\section{Conceptual framework: Environmental Impact Assessment (EIA)}

Environmental economics, whose central approach is that the correct application of market tools is sufficient to address environmental issues without sacrificing the ultimate goal of unlimited economic growth (Lizarazo, J. S. 2018). An important application of environmental economics is the Environmental Impact assessment, it is an environmental management tool made up of a series of procedures aimed at identifying, predicting and interpreting the impact generated by any human activity on the environment, with the objective of establish strategies to mitigate these effects (Cuesta, 2018). Currently there are different EIA methodologies, one of them is the Life Cycle Analysis (LCA), a tool for measuring the environmental impact by quantifying the flows of matter and energy linked to a product, process or system during its cycle of life, totally or partially, starting from the obtaining of the raw material, its processing, until its final disposal as waste (Labandeira et al., 2007). According to the Public Society for Environmental Management (2009), four different approaches to LCA are considered.

- $\quad$ From door to door (gate to gate): it consists of all the processes involved in the processing of a product, from its arrival as raw material to the "door" of the factory, until its exit as a finished product.

- $\quad$ From the cradle to the door (cradle to gate): it is made up of all the processes involved from the phase of extraction of raw materials, their transport and processing (if any), their transfer to the factory and production.

- From cradle to grave (cradle to grave): it refers to all the stages of the "cradle to the door" approach and also explores the phases of distribution to the client, its use and the management carried out as waste at the end of its useful life . 
- From cradle to cradle: includes all the processes analyzed in the "cradle to the grave" approach, that is, from raw material extraction to waste management.

The globally accepted norm for the Life Cycle Analysis is the one published by the International Organization for Standardization (ISO) known as ISO 14040: 2006, evaluation of the life cycle principles and framework. Following the guidelines proposed by the International Standard ISO (2006), the methodology for Life Cycle Analysis can be observed in Figure 1.

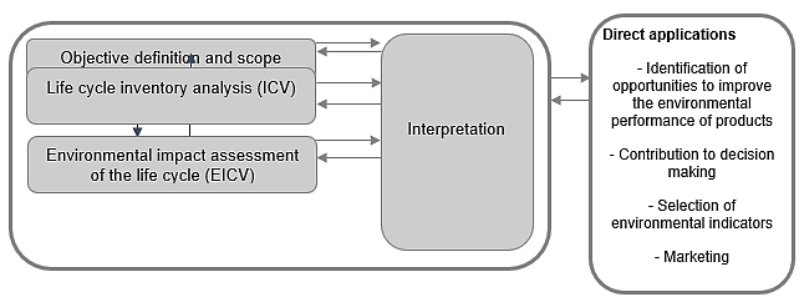

Figure 1 Stages of Life Cycle Analysis

Various computer tools have been developed to facilitate the widespread application of LCA, especially during the Evaluation stage of the life cycle inventory analysis (ICV), for which use is made of databases of processes, activities and preestablished materials. Among the most used ACV software are SimaPro, GaBi, Umberto, TEAM, OpenLCA. After reviewing the literature, it was found that the SimaPro software, developed by the Dutch company PRé Consultants, is one of the most used programs for Life Cycle Analysis; Several investigations around the world have resorted to this due to its multiple functionalities, among which the incorporation of the most important databases such as Ecoinvent, ILCD, Agri-footprint and the creation of own databases, in addition to using the methodologies of the most up-to-date impact assessment, such as: ILCD 2011 Midpoint +, CML - IA baseline, ReCiPe 2016, IPCC 2013 and Traci 2.1., characteristics that provide studies with a higher level of truthfulness and reliability (Instituto Superior de Medio Ambiente, 2017). Therefore, in the present investigation the SimaPro software was used in its version V8.5.2, to apply the Life Cycle Analysis in the company case study.

\section{Cactus industry in Mexico}

Belonging to the opuntia genus of the family of cacti, the cactus, also known as nopal vegetables or nopalitos, is a species native to America, with a special presence in Mexico, center of greater diversity of cacti and nopales of the continent. Since pre-Hispanic times, the nopal has occupied an important place in the gastronomy, history and culture of Mexico being today a basic element in the diet of Mexicans and an icon of their identity (Valencia-Sandoval, BrambilaPaz, \& Mora-Flores, 2010).

The nopal is a very rich fiber food that helps a good digestion, it also contains vitamin $A$, vitamin $C$, vitamin $K$, riboflavin, vitamins B5, B6, B12 and minerals especially calcium, sodium, potassium, magnesium, iron. Given its nutritional and medicinal properties, nopal are currently demanded by some communities in the United States, Canada, Japan, Italy and Turkey, with Mexico being the number one producer worldwide (Osorio-Córdoba et al., 2011). Figure 2 shows the parts of the cactus plant, Milpa Alta variety, which is characterized by being robust, erect, with oval-shaped cladodes, with high productivity in summer and sensitive to low temperatures. The fruit, known as prickly pear, is of medium size, with yellow-orange peel and pulp, not very juicy, with medium-sized seeds (FAO, 2018).

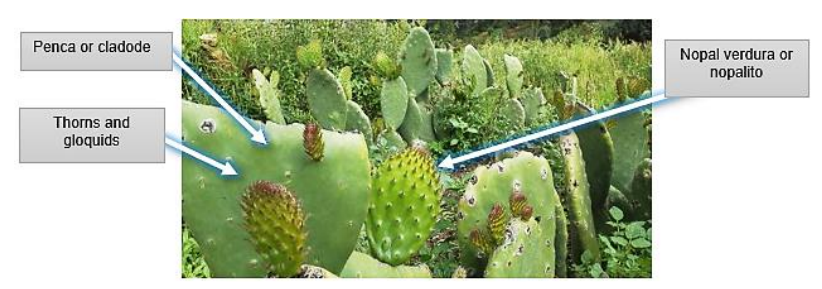

Figure 2 Parts of the cactus plant indicates Milpa Alta variety

Source: image taken in situ and adapted from OsorioCórdoba et al., (2011)

According to the Agrifood Atlas published in 2018 by the Agrifood and Fisheries Information Service (SIAP) of the Ministry of Agriculture, Livestock, Rural Development, Fisheries and Food (SAGARPA), the national cactus production has had a steady increase in the last decade. As can be seen in Figure 3, from 2006 to 2017, on average Mexico has produced 785 thousand tons of nopal vegetables per year. 


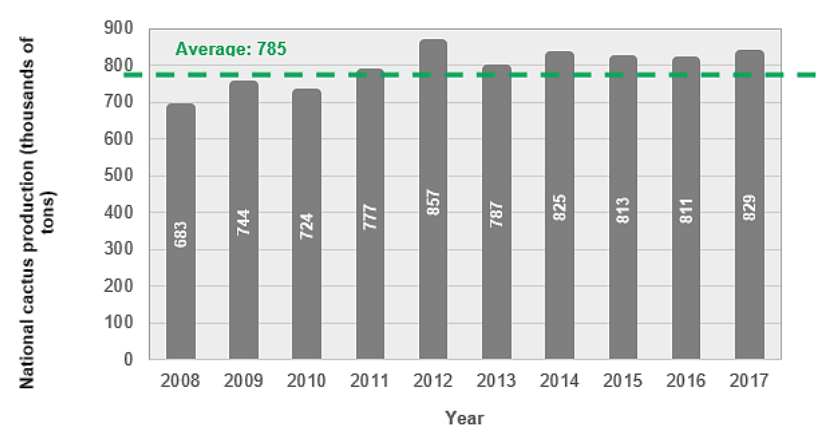

Figure 3 National volume of cactus production in thousands of tons (2006-2015)

Source: own elaboration based on data from SIAP (2018)

For 2017, Mexico produced 829 thousand tons, of which, $45.26 \%$ corresponded to the state of Morelos, $24.58 \%$ to Mexico City and $10.94 \%$ to the State of Mexico, it is in these three federative entities where the $80.78 \%$ of the national production of nopal vegetables (SIAP, 2018).

\section{Case study company}

The case study carried out in the present investigation consisted of a family business, $100 \%$ Mexican dedicated for more than 20 years to the production, processing and distribution of nopal vegetables and derivatives, located in the town of San Gregorio Atlapulco de la Mayor of Xochimilco in Mexico City.

As additional information, it is important to mention that, during the year 2017 , the case study company processed an average of one ton of nopal vegetables for the production of 800 units of nopal in brine of 1.2 kilograms $(\mathrm{kg})$ per day in a shift of 8 hours; It also has an area of seven hectares located in the lower area of the Tehutli volcano in Milpa Alta, a key region where the main nopal producers in Mexico are located.

Given the increase in demand for its products, its cultivation capacity reached the limit, so it also buys part of its raw material from third parties, given the strategic relationship it maintains with around 100 nopal vegetable producers in the Milpa Alta area with which it integrates a cluster.

Figure 4 shows the geographical location of the cultivation and processing area of the company case study.

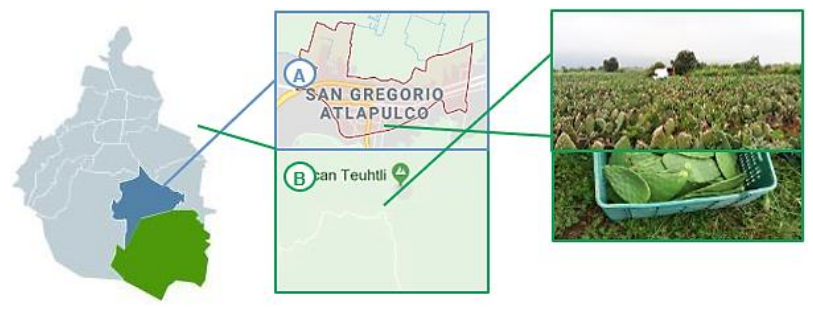

Figure 4 Geographic location of the processing plant (A) and the nopal cultivation area (B)

Source: images taken in situ with information from Google Maps (2017)

The nopal cultivated by the case study company and its suppliers, is planted in open field orchards, sometimes under plastic cover according to bad weather conditions. Regarding the methods of fertilization, the producers in the Milpa Alta area carry out a mixed system that includes the use of manures and chemical or mineral fertilizers, a combination that has had positive impacts on crop yield and nutritional quality of the product. Occasionally maintenance of prickly pear leaves is done manually in order to guarantee efficient production of nopal vegetables and prevent the plant from growing irregularly or spreading a pest throughout the crop. Finally, the collection of nopal vegetables is an artisanal activity characterized by the extraction of cladodes after 30 and 60 days of sprouting.

The transport of the harvested prickly pear from the cultivation area to the processing plant is carried out using the vehicle of the case study company, traveling on average eight kilometers $(\mathrm{km})$ per day per route. The transformation of fresh prickly pear cactus into brine carried out by the company case study consists of the production processes: cut and unpinned, washed, chopped, cooked, packedsealed, cooled and labeled-embedded.

\section{Methodological framework: Application of Life Cycle Analysis (LCA)}

The first step for LCA was the definition of the objective and scope of the study; The first was aimed at identifying the environmental impact associated with the process of cultivation of nopal vegetables and its process of transformation into prickly pear cactus in the company's case study. It is important to mention that the LCA methodology was adapted to the specific conditions of the company. 
Regarding the scope, the functional unit selected for the study corresponded to a ton of prickly pear cactus and the system limits followed a "Cradle to Door Gate" approach, that is, they were taken into account the stages concerning from the cultivation and harvest of prickly pear, transport to the plant and its process of transformation in prickly pear cactus in brine, as observed in Figure 5, where the dotted line denotes the delimitation of the system including all activities analyzed and in turn, excluding subsequent phases that were not part of the study, such as storage, distribution, product consumption, end of life and final disposal as waste.

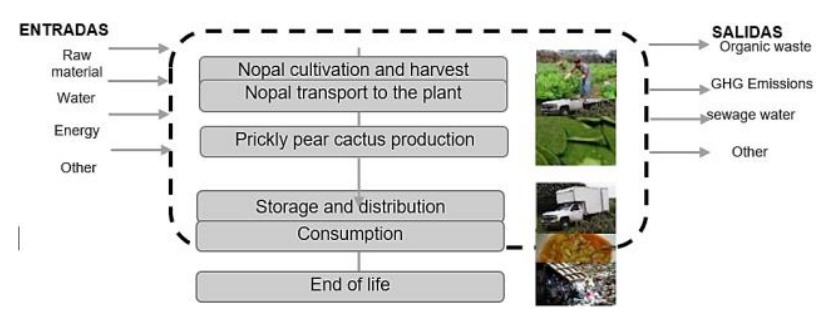

Figure 5 System Limits for LCA

Source: own elaboration obtained with information in situ, 2017

The second phase of the LCA consisted of the Life Cycle Inventory, which was comprised of the definition and quantification of the inputs of natural resources, raw material and energy to the system, as well as their outputs in emissions to air, water and water. soil, for which it was necessary to collect data from the company case study which was complemented with information from other producers in the region and secondary sources referring to the sector. Among the information collected from the nopal producers, the following were considered: crop variety, growth cycle, harvest planting date, yield of fresh and dry matter, planting density, crop management, rotation, irrigation, used machinery, pruning tillage method. In addition, data concerning the fertilization methodology applied in the cactus cultivation were extracted, as well as the phytosanitary treatments used. On the other hand, from secondary sources of information such as the United Nations Food Organization (FAO, 2015), the Intergovernmental Panel on Climate Change (IPCC, 2006), Sagarpa (SIAP, 2018), AGROASEMEX (2011) and the Ministry of Environment and Natural Resources (SEMARNAT, 2016).
Information related to geographic data of the cultivation area, agroclimatic zone, rainfall and evapotranspiration was taken as reference, as well as soil data such as texture, type, depth, structure, $\mathrm{pH}$, percentage of clay, sand, silt, organic matter and nitrogen.

The Emissions Calculation Matrix for the agricultural sector, developed in the framework of the LIFE and Futur Agrari project (LIFE + Farms for the future LIFE12 ENV / ES / 000647), was used to calculate the emissions of the cactus cultivation conducted by researchers from different countries in Europe (Antón Vallejo et al., 2017). With the objective of guaranteeing the rigor of the present investigation, it was attempted to use mostly data from the Mexican context, however, the calculation of GHG emissions in Mexico, the research on LCA are still emerging issues, so part of The data used corresponded to European standards, extracted mainly from official reports of the European Environment Agency (EEA, 2013). Even with the slight variations that they bring, European standards represent a good role model and open the door for future research conducted in Mexico to direct their efforts towards the creation of a database of their own and consistent with the national agricultural dynamics.

\section{Results: Life Cycle Impact Assessment (EICV)}

The third stage of the LCA corresponded to the Life Cycle Impact Assessment, for which the SimaPro V8.5.2 software was used. In Table 1, the categorization of the inventory analysis data for the nopal cultivation stage can be observed.

During this phase several elements intervened, the cactus's own cultivation, the use of mineral fertilizers such as Multi NPK (nitrogen, phosphorus and potassium), potassium sulfate, monoammonium phosphate, calcium nitrate and the generation of solid waste.

The results correspond to the environmental impacts for the cultivation of a kilogram of nopal vegetables. 
The SimaPro software yields a total of 18 impact categories which are Climate Change, Stratospheric Ozone Depletion, Ionizing Radiation, Ozone Formation, Human Health, Fine Particle Formation, Ozone Formation, Terrestrial Ecosystems, Terrestrial Acidification, Water Eutrophication Sweet, Marine Eutrophication, Terrestrial Ecotoxicity, Freshwater Ecotoxicity, Marine Ecotoxicity, Human Carcinogenic Toxicity, Human NonCarcinogenic Toxicity, Land Use, Scarcity of Mineral Resources, Scarcity of Fossil Resources and Water Use.

However, based on literary review, literary review and experience, only 12 of these were taken into account because they were the most significant with the research.

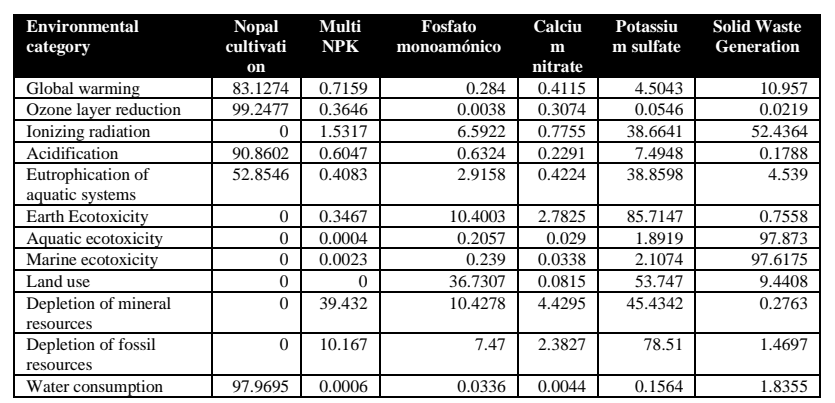

Table 1 Impact categories - Nopal cultivation stage $(1 \mathrm{~kg})$

In Figure 6, the results of inventory analysis for the crop stage are presented graphically, each activity was assigned a different color for better interpretation.

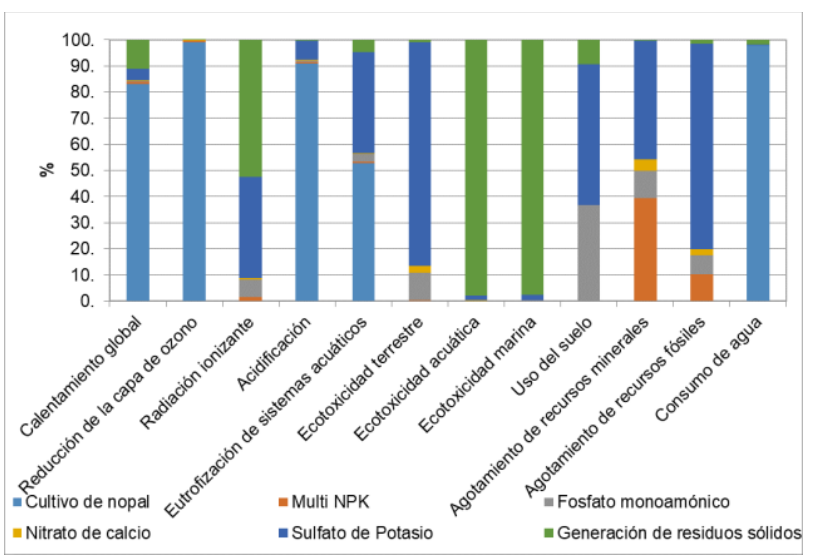

Figure 6 Bar chart - Nopal Cultivation Stage

Source: own elaboration based on the result of the application of the SimaPro V8.5.2 software

As can be seen in Figure VI, Prickly pear cultivation is not a process beyond global warming, in fact, it seriously contributes to the emission of greenhouse gases that generate this phenomenon.
Similarly, it can be seen that it presents important opportunities for improvement in the categories of ozone reduction, acidification, eutrophication of aquatic systems and water consumption. For its part, the generation of solid waste is an activity that demands a prompt solution as its responsibility is evident in the categories of impact of ionizing radiation and aquatic and marine ecotoxicity. Finally, the production of mineral fertilizers does not represent a significant value, except for that concerning potassium sulfate, since it can be observed that it is present in the categories of terrestrial ecotoxicity, land use and depletion of natural resources. In turn, Table 2 and Figure VII show the categorization of the inventory analysis data for the nopal transport phase from the cultivation area to the processing plant. During this stage, in addition to transportation, the production of the fuel used was also included, in this way two elements were analyzed for one ton per kilometer traveled.

\begin{tabular}{|l|r|r|}
\hline \multicolumn{1}{|c}{ Label } & \multicolumn{1}{c|}{$\begin{array}{c}\text { Transportation } \\
\text { crop to plant }\end{array}$} & \multicolumn{1}{c|}{ Fuel } \\
\hline Global warming & 95.8865 & 4.1135 \\
\hline Ozone layer reduction & 88.8846 & 11.1154 \\
\hline Ionizing radiation & 0 & 100 \\
\hline Acidification & 84.5582 & 15.4418 \\
\hline Eutrophication of aquatic systems & 0 & 100 \\
\hline Earth Ecotoxicity & 98.7184 & 1.2816 \\
\hline Aquatic ecotoxicity & 58.2499 & 41.75 \\
\hline Marine ecotoxicity & 87.9297 & 12.0703 \\
\hline Depletion of mineral resources & 0 & 100 \\
\hline Depletion of fossil resources & 0 & 100 \\
\hline Water consumption & 0 & 100 \\
\hline
\end{tabular}

Table 2 Impact categories - Nopal transport stage (1 Ton $/ \mathrm{km})$

Source: own elaboration based on the result of the application of the SimaPro V8.5.2 software

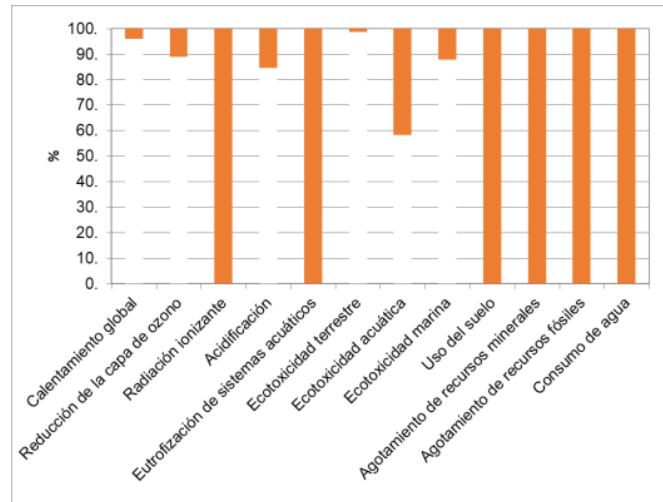

Figure 7 Bar chart - Nopal transport stage (one ton per kilometer)

Source: own elaboration based on the result of the application of the SimaPro V8.5.2 software
TAVERA-CORTÉS, María Elena, SANDOVALGÓMEZ, Raúl Junior and VERGEL-RANGEL, Guillermo Alexis. Environmental impact assessment in a company. RINOE Journal-Financial Economv. 2019 
It can be seen in Figure 7, that transport activity has the highest percentage in each category, especially global warming, terrestrial ecotoxicity and reduction of the ozone layer, which is consistent with official information from the National Inventory of Greenhouse Gases from Mexico (INEGI), where the transport sector is part of the main GHG emitters. Similarly, Table 3 and Figure 8 present the categorized data for the inventory of the processing stage of prickly pear cactus in brine, final phase of the analyzed system.

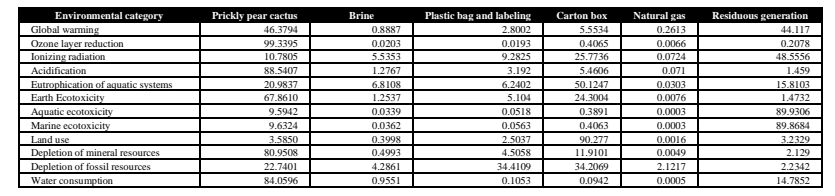

Table 3 Impact categories - Nopal processing stage (one ton)

Source: own elaboration based on the result of the application of the SimaPro V8.5.2 software

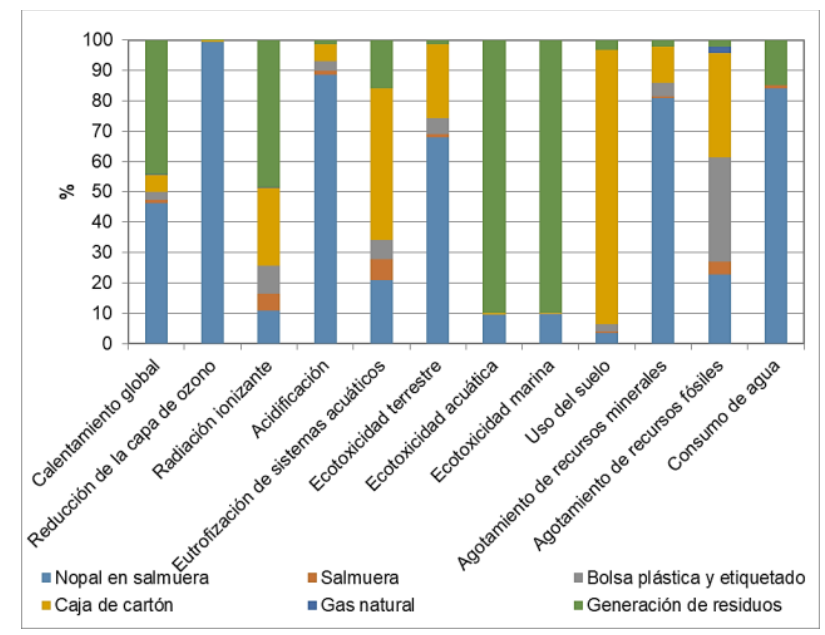

Figure 8 Bar chart - Processed Phase (1 Ton)

Source: own elaboration based on the result of the application of the SimaPro V8.5.2 software

As detailed in Figure 8, the prickly pear cactus production process consists of several sub processes, in which different elements such as brine ingredients and manufacturing materials such as plastic bag and cardboard box are involved. . In addition, during the process natural gas is consumed as fuel for the cooking activity and solid waste is generated. During the process of producing prickly pear cactus in brine, large amounts of water are consumed, which after their assignment are discharged into the drainage without any prior treatment. Similarly, large quantities of organic waste are generated, which are not given an appropriate treatment either.
This was reflected in the environmental performance of the phase, especially in the category of global warming. Once the processes have been analyzed separately, the system analysis is presented below, which consisted of the study together. Figure 9 shows the environmental impact categories and the three phases with their respective values.

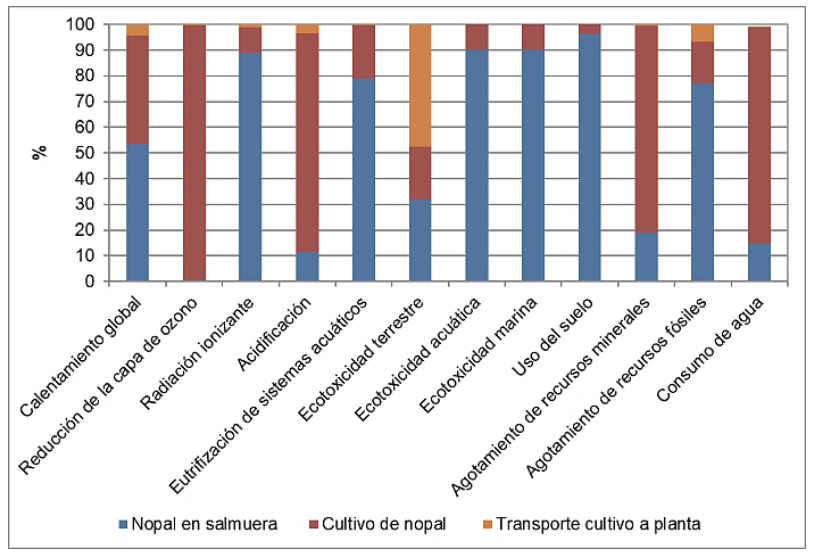

Figure 9 Impact categories Cultivation, Transportation and Processing

Source: own elaboration based on the result of the application of the SimaPro V8.5.2 software

As can be seen in Figure 9, in the Global Warming category, the Nopal Production in Salmuera represents the activity of the system with the worst environmental performance with a $53.62 \%$ participation, mainly derived from the generation of solid waste responsible for the emission of significant amounts of methane and nitrous oxide, as mentioned in the previous section. It is important to mention that the Nopal Cultivation also contributes significantly to this category by contributing $42.01 \%$, as it is also responsible for the emission of nitrous oxide and methane into the atmosphere due to the application of mineral fertilizers and manure respectively.

For its part, Transport activity is the one with the lowest participation $(4.36 \%)$, because the distance traveled between the cultivation area and the plant is not too long, and therefore, its GHG emission is not as relevant as in the previous activities. In this way, it can be concluded that the activities that have the greatest environmental impact in the nopal life cycle in brine are the generation of solid waste in the cultivation and processing stages and the application of mineral fertilizers and manure as fertilizer. 


\section{Discussion}

Various similar results were obtained in similar or close studies in this case study in the culture stage. In order to make the comparison, the carbon footprint of the nopal vegetable was first studied. In Figure 10, the Saney diagram or also called a tree diagram is presented (Freund et al, 2000), where you can see in detail the total greenhouse gas emissions in $\mathrm{CO} 2$ corresponding to the production of $1 \mathrm{~kg}$ of cactus Vegetable per year. The thicker red lines express the flow of greatest impact according to the amounts provided in the program.

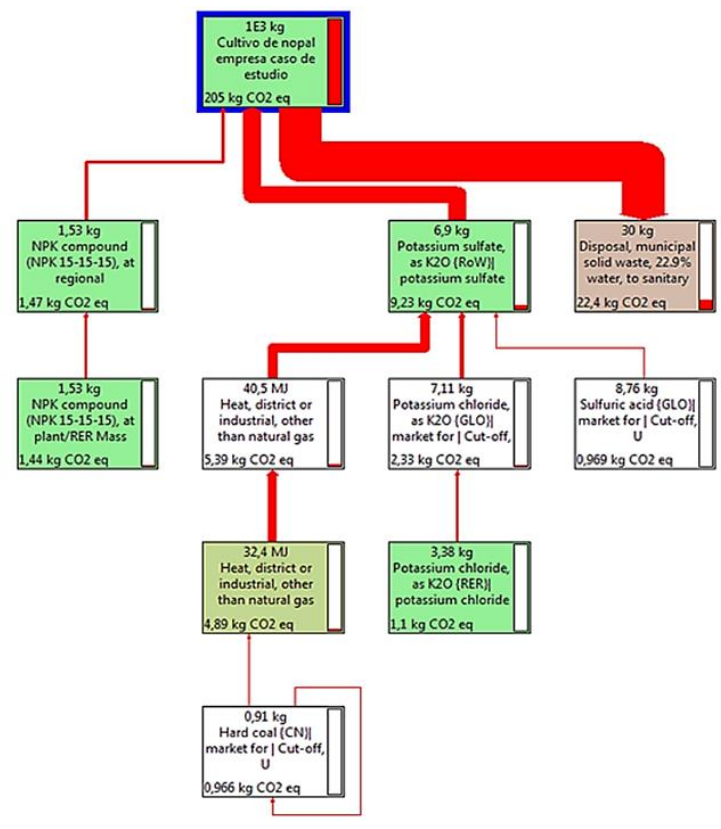

Figure 10 Sankey diagram - Nopal cultivation Source: own elaboration based on the information collected

Table 5 shows agricultural products from different countries around the world with their respective carbon footprint in $\mathrm{CO} 2$ per kilogram produced. Making the comparison with the results obtained in the present investigation it can be observed that the environmental impact of the cactus is similar to that of products such as sweet corn from the United States and apples from Italy. However, it is much smaller compared to other products such as New Zealand Kiwi or Moroccan asparagus. It is important to mention that this comparison was made without taking into account other parameters of each agricultural crop, therefore, for future research it would be convenient to study the performance of the nopal vegetable with other products with similar characteristics, for example, to study the nopal carbon footprint produced by the three entities with the highest production in Mexico.

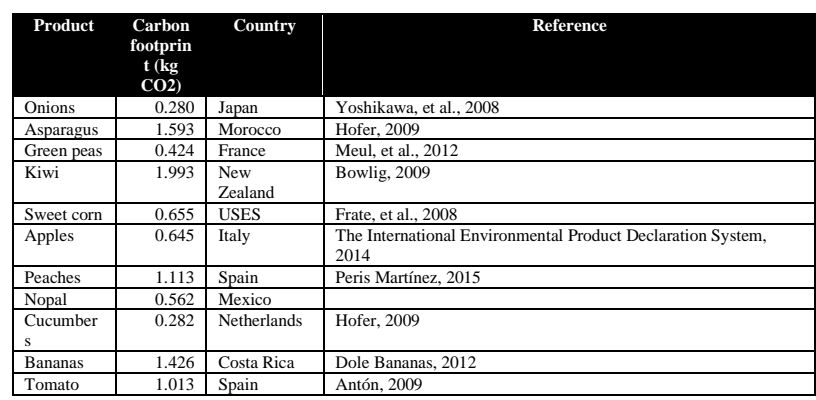

Table 5 Comparison carbon footprint agricultural products around the world

Source: own elaboration based on the result of the application of the SimaPro V8.5.2 software

\section{Conclusions}

After analyzing the dynamics of the cactus industry in the area of Milpa Alta, Mexico City, where the case study company is located, it can be affirmed that a traditional production system still prevails, characterized by the use of rudimentary techniques of cultivation and fertilization, highlighting the complete absence of environmental management, mainly due to ignorance and lack of training of producers.

The study carried out in the present investigation confirms the importance of the Environmental Impact Assessment as one of the solutions to the problem that exists today in environmental matters in the agricultural sector, mentioned above and that is mainly caused by the disproportionate emission of greenhouse gases into the atmosphere that has triggered the phenomenon known as global warming.

The case study carried out in a nopal producing and processing company consisted in the application of a Life Cycle Analysis (LCA) to the brine cactus product, whose system covered the cultivation, transport and processing stages. Thanks to the different visits made to the company, information was collected and, together with secondary sources, the quantification of the life cycle inventory was carried out, which highlights the emission of greenhouse gases.

During this process, some limitations were found regarding prior information. In Mexico, the National Emissions Registry still has great opportunities for improvement and there is not enough data to carry out a deeper analysis. 
However, with the results obtained life cycle analysis using SimaPro V8.5.2 software, it was identified that the process of nopal production in brine does not present an optimal environmental performance, analyzing the three phases of the system, it was observed that each it presents important opportunities for improvement, especially, the nopal cultivation stage, which, as mentioned earlier, lacks environmental management. It is necessary to point out that the cactus cultivation is not a process outside of global warming, since it seriously contributes to the emission of greenhouse gases that generate this phenomenon. On the one hand, mineral fertilizers, responsible for the emission of nitrous oxide into the atmosphere, are presented as GHG, which represents $50.4 \%$ of the emissions of the agricultural sector in equivalent units of carbon dioxide.

Likewise, the use of manure of bovine or equine origin as fertilizer, although it seems otherwise, is also an important emitter of methane $(\mathrm{CH} 4)$ and nitrous oxide $(\mathrm{N} 2 \mathrm{O})$, (Herran et al, 2008). Therefore, within the recommendations for this phase, there is the gradual replacement of the fertilization model used by a more environmentally friendly one that does not sacrifice productivity or the quality of the final product, one of the solutions currently is the compost application.

\section{References}

AGROASEMEX (2011) "Mapa Nacional de Erosión Potencial", Tecnología y ciencias del agua, 2(1), pp. 5-17. Disponible en: http://www.scielo.org.mx/pdf/tca/v2n1/v2n1a1. pdf.

Antón Vallejo, A. et al. (2017) Cálculo de emisiones debidas a la aplicación de fertilizantes. Disponible en: http://www.futuragrari.cat/4/documentacio_tec nica_563781.html.

Ayala, A. V. et al. (2011) "Determinación de la competitividad del sector agropecuario en méxico, 1980-2009", Revista Mexicana de Ciencias Agrícolas, 2(4), pp. 501-514. Disponible en: http://www.scielo.org.mx/pdf/remexca/v2n4/v2 n4a3.pdf.
Cuesta Aguirre, R. L. (2018). La curva de kuznets como herramienta para medir el desarrollo económico y el equilibrio ambiental: revisión sistemática.

EEA (2013) "EMEP/EEA air pollutant emission inventory guidebook 2013: Technical guidance to prepare national emission inventories", EEA Technical report, (12/2013), p. 23. doi: $10.2800 / 92722$.

FAO (2015) Estimación de emisiones de gases de efecto invernadero en la agricultura. doi: 97892-5-308674-0.

FAO (2018) Ecologia del cultivo, manejo y usos del nopal, Boletín De Servicios Agrícolas De La Fao. Disponible en: http://www.fao.org/3/i7628es/I7628ES.pdf.

Freund, J. E., Miller, I., \& Miller, M. (2000). Estadística matemática con aplicaciones. Pearson Educación.

Herrán, J. A. F., Torres, R. R. S., Martínez, G. E. R., Ruiz, R. M., \& Portugal, V. O. (2008). Importancia de los abonos orgánicos. Ra Ximhai: revista científica de sociedad, cultura y desarrollo sostenible, 4(1), 57-68.

IPCC (2006) Directrices del IPCC de 2006 para los inventarios nacionales de gases de efecto invernadero, IPCC. doi: 10.1017/CBO9781107415324.004.

ISO - Organización Internacional de Normalización (2006) 14044:2006 Gestión Ambiental - Análisis de Ciclo de Vida Principios y marco. Ginebra.

Lizarazo, J. S. (2018). Economía Ecológica y la construcción epistemológica de una ciencia revolucionaria para la sostenibilidad y la transformación del mundo. Gestión y Ambiente, 21(1supl), 13-34.

Osorio-Córdoba, J. et al. (2011) "Conservación de nopal verdura 'Milpa Alta' (opuntia ficus mdica mill.) desespinado en envases con atmosfera modificada", Revista Mexicana de Ingeniera Qumica, 10(1), pp. 93-104. 
Paz García, A. P., Imhoff, D., Vieyra, C., \& López, N. (2018). Tratamiento de los temas soberanía y seguridad alimentarias en medios de comunicación hegemónicos y alternativos (Córdoba, Argentina, 2012-2015). Estudios sociales (Hermosillo, Son.), 28(51), 0-0.

Santoyo, A. H., Vilardell, M. C., Sánchez, M. A. L., Fernández, R. C., \& León, V. E. P. (2013). La Ciencia Económica y el Medio Ambiente: un aporte desde la valoración económica ambiental. Revista Paranaense de Desenvolvimento-RPD, 34(125), 25-38

SEMARNAT (2013) Inventario Nacional de Emisiones de Gases de Efecto Invernadero 1990-2010. doi: 10.1017/CBO9781107415324.004.

SEMARNAT (2016) Sistema Nacional de Indicadores Ambientales. Disponible en: http://apps1.semarnat.gob.mx/dgeia/indicadores 16/index.html.

SIAP (2018) Atlas agroalimentario 2018. Disponible en: https://nube.siap.gob.mx/gobmx_publicaciones _siap/pag/2018/Atlas-Agroalimentario-2018.

Vega Campos, M. Á., Medina Jiménez, A. y Vega Juárez, M. Y. (2013) "Los sistemas de gestión ambiental y su aplicación en la industria agropecuaria de México: una breve revisión del tema", Entreciencias, 1(2), pp. 197-210. 